\title{
MENEMUKENALI MASYARAKAT ADAT \\ SEBAGAI BASIS "KEBHINNEKATUNGGALIKAAN" \\ MENUJU INTEGRASI BANGSA
}

\author{
Oleh: Djaja Hendra*
}

\begin{abstract}
Put the indigenous peoples to be followed by the term "all still alive and in accordance with the development of society" or other terms that convey the same in the constellation of state regulations, no doubt point to the existence of ideological claims unilateral and provocative. On the one hand, indigenous peoples as being faraway, while we are on the other side so arrogant and intervention while differentiating themselves into, "so another". Disorder was demonstrated through planned regulatory policies, structural and massive for our indigenous people buried in the frame word 'all still alive' and so on. Though there are many other socio-cultural based that sustains the existence and survival on indigenous peoples outside of agriculture. The Kebhinnekatunggalikaan was eminent merely ended motto compliance rigid beliefs and unilateral. If so integration with the nation as the adhesive is based on the awareness of the need for unity in fact not be as, a mere mirage.
\end{abstract}

Key Words: Indigenous peoples, all still alive, the integration of the nation

\section{Pendahuluan}

Ada banyak harapan dilekatkan pada Pancasila dengan semboyan kebhinnekatunggalikaan. Harapan demikian telah muncul sejak kita mengenalnya melalui pendidikan formal yang diajarkan di sekolah-sekolah hingga bangku kuliah maupun di pendidikan nonformal dan informal. Ada yang melihatnya dari sudut pandang ideologis, filosofis, yuridis, sosiologis maupun kultural. Dengan begitu maka, tak dapat diingkari bahwa lambang negara kita begitu berwibawa sebagai simbol pemersatu sehingga ditempatkan begitu tinggi dan diagungkan. Nilai-nilai Pancasila diyakini mampu membentuk karakter bangsa baik dalam kaitannya dengan tatanan ketatanegaraan maupun dalam kehidupan berbangsa.

Dari sudut pandang ideologis, filosofis maupun politik Pancasila di dalam tatanan bernegara cukup handal terutama dalam menghadapi berbagai rongrongan dan rintangan yang dicerminkan dari keberhasilan dan kemampuan menciptakan demokratisasi pemerintahan maupun ketatanegaraan. Rendahnya separatis, tertatanya siklus lima tahunan pergantian rezim dan makin menguatnya otonomi daerah menggambarkan mekanisme dan proses bernegara sedang telah berjalan. Namun bukti-bukti yang menggembirakan

\footnotetext{
* Dosen pada Universitas Widya Mataram Yogyakarta. Email: djajahendraaa@gmail.com
} 
itu ternyata belum sejalan jika dipotret dari aspek kebangsaan khususnya dari sudut pandang sosiologis maupun kultural. Implementasi dan penerjemahan semboyan kebhinnekatunggalikaan nampak masih tertatih-tatih, berjalan ditempat bahkan mundur. Suasana itu ditunjukkan melalui perjalanan anak bangsa yang sudah lebih dari setengah abad, dimana posisi Pancasila dan kebhinennekaan acapkali dipergunakan sebagai pemukul, ketika beragam nasion yang terhubung dan membentuk Nusantara, tidak sejalan dengannya. Padahal entitas sosial atau nasion-nasion itu telah lama ada bahkan sebelum negara Indonesia terbentuk (Bachtiar, 1976: 7). Eksistensi dan survivalitas mereka --yang kemudian dikenal dengan masyarakat adat itu-- terus tumbuh dan berkembang secara alamiah tanpa perlu campur tangan negara.

Jika demikian tidak kelirulah apa yang dikatakan Marx bahwa negara demokratis, bersifat dermawan, dan berposisi sebagai lembaga yang netral itu, tidak pernah ada di muka bumi ini. Negara pada dasarnya memiliki banyak kepentingan. Negara adalah sebuah lembaga atau alat yang diperuntukkan bagi memenuhi kepentingan elite penguasa yang menjalankan roda pemerintahan. Secara demikian maka dapat saja sebuah negara dikategorikan sebagai kapitalis, sosialis atau mungkin juga pancasilais, dengan diikuti oleh sistem politik otoriter maupun demokratis, ataupun irisan-irisan di antara itu; namun dalam praktik kenegaraan dapat berbeda dan bahkan bertolak belakang. Praktik kebijakan itu berlangsung manakala dilakukan dan dijalankan oleh orang atau sekelompok orang atau aktor-aktor politik yang menguasai negara. Dalam bahasa politikpemerintahan mereka dikenal sebagai rezim penguasa. Gramsci lebih menyebut mereka sebagai intelektual organis (Femia, 1977: 24).

Sosok rezim atau intelektual organis, dengan begitu, muncul dan terlahir dari rahim entitas sosialnya. Mereka adalah sekelompok kecil orang dan memiliki kelebihan-kelebihan sehingga dengan demikian mereka bukan orang sembarangan. Intelektual organis pastilah berbeda dari orang kebanyakan. Untuk Indonesia, mereka hadir di awal abad ke20 dan kiprah utama mereka terlihat dari lahirnya Boedi Oetomo menyusul organisasi-organisasi sejenis. Meski ideologi masih bersifat lokal dan parsial tetapi langkah-langkah yang dibangun memiliki kesamaan-kesamaan sehingga sikap demikian dijadikan tonggak sejarah perjuangan bangsa hingga kemerdekaan.

Kenapa mereka dapat hadir di tengah masa-masa sulit akibat penindasan? Siapa mereka? Berdasarkan sejarahnya intelektual organis, yang adalah bagian 
dari entitas sosial masyarakatnya, di masa kolonial bergantung pada kedudukan dan posisi orang-orangtua mereka. Para orangtua dari intelektual organis adalah sekelompok orang terpandang baik secara sosial, politik maupun kultural. Sebutan bagi mereka yaitu pangreh praja atau priyayi, kelompok bangsawan, ningrat, guru, rohaniwan, tuan tanah dan elite sosial lainnya. Mereka dihormati dan karenanya terbedakan dari rakyat kebanyakan. Gramsci menyebutnya sebagai intelektual tradisional. Mereka dicirikan dari tata cara kehidupan dan tutur bahasa yang teratur, berdisiplin tinggi serta memiliki hierarki dalam keluarga maupun sistem sosial lain. Komunitas ini membentuk tatanan kehidupan tersendiri lepas dari sosiokultural masyarakatnya (Wertheim. 1999: 43) namun dekat dengan pemerintah kolonial karena sifat dan fungsi pelayanannya. Artinya mereka adalah perpanjangan tangan dalam struktur pemerintahan kolonial.

Jadi intelektual organis ini terlahir melalui rahim dari elite dalam entitas sosialnya atau intelektual tradisional. Meski tidak seluruhnya seperti itu tetapi tidak dapat dipungkiri bahwa generasi yang demikian menjadi tidak peka dan sensitif atas masyarakatnya. Di satu sisi mereka sibuk menata diri dan menuntut persembahan atas rakyatnya; tetapi di sisi lain mengambil posisi merendah dan penghambaan-diri dihadapan pemerintah kolonial. Sartono Kartodirdjo menyebutnya sebagai saling kontradiktif (Sutherland, 1983: 74). Dalam posisi inilah maka setiap pergantian rezim dan ketika mereka menjalankan fungsi pemerintahan atau negara jangkauan dan raihan atas masyarakat adat nyaris tidak terwacanakan apalagi dalam bentuk kebijakan yang menguntungkan dan adil. Ini semua sebagai konsekuensi dari kontradiktif kepentingan tadi. Masyarakat adat dalam praktiknya berjalan sendiri sehingga terkesan ada jarak dengan rezim pengaturnya. Di sinilah Pancasila dengan Bhinneka Tunggal Ika sebagai wadah tunggal atas semua entitas sosial dituntut keterujiannya.

\section{Posisi Masyarakat Adat dalam} Keanekaan Struktur Masyarakat Indonesia

Struktur masyarakat Indonesia ditandai oleh sekumpulan nasion yang teruntai memanjang mengikuti garis khatulistiwa atau yang dikenal dengan Nusantara. Mereka memiliki ragam, corak yang beraneka dan sosiokultural yang berbeda, namun bergerak di atas suatu sistem ekologi, teknologi, demografi dan klimatologi yang sama. Secara sistematis Wertheim (1999: 1-2) mencirikan perbedaan pada: pertama, perbedaan geografi. Perbedaan dibuktikan dari 
banyaknya pulau baik besar maupun kecil tetapi dengan akar genealogis yang sama. Kedua, perbedaan pada etnik. Perbedaan yang bertolak dari perbedaan budaya dan bukan pada ras dalam pengertian rasial. Ketiga, perbedaan terkait dampak teknologi yang ditimbulkan. Akibat dampak teknologi yang berlangsung selama berabad-abad menimbulkan peradaban yang sangat berbeda.

$$
\text { Rangkaian perbedaan yang }
$$

membentuk struktur masyarakat Indonesia itu tetap hidup seirama alam lingkungannya. Kehidupan demikian dikenal dengan sosiokultural. Adalah kelompok atau komunitas orang yang menggunakan berbagai cara untuk beradaptasi dengan lingkungan, bertindak menurut bentuk-bentuk perilaku sosial yang sudah terpolakan, dan menciptakan kepercayaan dan nilai bersama yang dirancang hidup untuk memberi makna bagi tindakan kolektif mereka (Sanderson, 2003: 59). Sehingga tidak tertutup kemungkinan jika mendasarkan pada prinsip-prinsip sosiokultural tadi, maka kecil kemungkinkan mereka akan berperilaku menyimpang dan menggerus kewibawaan negara (korupsi); dibandingkan dengan mereka yang sematamata bekerja karena adanya peluang dan akses yang terhubung di sektor jasa maupun di birokrasi-pemerintahan (diluar sosiokultural).
Lebih lanjut, berdasarkan perbedaan yang ada struktur masyarakat Indonesia dapat dilihat dari dua sisi, yaitu: horizontal dan vertikal.

\section{Perbedaan Horizontal dalam Struktur Masyarakat Indonesia}

Adanya perbedaan-perbedaan jika dilihat dari sisi horizontal adalah sebuah fakta sosial. Perbedaan ditandai oleh beragam suku, bahasa, agama, adat istiadat, etnik maupun kedaerahan; yang merupakan bentuk asli maupun akulturasi, berdasar dimensi waktu dan ruang di mana satu sama lain telah berproses begitu lama dan panjang hingga berabad-abad. Perbedaan-perbedaan inilah yang melandasi dalam cara bersikap dan berpikir, sehingga karakter-karakter yang muncul dalam konstelasi pergaulan antarnasion menjadi berbeda pula. Awalnya mereka hidup sendiri-sendiri dan membentuk nasion-nya sendiri, terpisah satu sama lain dengan tanpa dibalut oleh suatu kesatuan politik yang sama. Perbedaan-perbedaan itu kata Nasikun (1989: 33) dapat dirumuskan sebagai sesuatu yang, memiliki ketidaksamaan kehendak bersama (common will), sekaligus memiliki ketidaksamaan permintaan sosial yang dimengerti dan dihayati bersama oleh seluruh nasion (common social demand). 
Dengan tidak adanya permintaan sosial yang sama secara ekonomi dan dengan dibimbing oleh ketidaksamaan kehendak bersama maka peluang dan potensi konflik diantara mereka menjadi laten dan terendap. Terlebih di atas segala perbedaan-perbedaan yang ada justru akan semakin tajam dan sewaktu-waktu dapat meledak ketika semua itu bermuara pada kepentingan ekonomi dan jatuh dalam libatan etnis (Tionghoa). Kerusuhan Mei 1998 merupakan perwujudan dari titik simpul itu. Sedang yang terbaru adalah jelang dan pasca pemilihan anggota legislatif dan presiden 2014 lalu. Keterpilihan dan kedudukan mereka saat ini sebagai elite politik terpulang dan berangkat dari mudahnya akses informasi dan komunikasi antardaerah yang dibentuk dan direkayasa secara sosial (tidak alami). Pembentukan gaya tersebut harus terus dipacu dan dipertahankan secara sedemikian rupa hingga periode kepemimpinan itu berakhir. Jika tidak, tidak tertutup kemungkinan isu-isu kekerasan agama, kedaerahan, suku dan etnis berpotensi muncul, mengingat 'pendeknya sumbu' dinamit sosial. Akibatnya dengan sentuhan sedikit saja sudah cukup menimbulkan gejolak dan ledakan sosial. Sekurang-kurangnya kenyataan demikian itu telah menjadi agenda tahunan di Propinsi Daerah Istimewa Yogyakarta.

\section{Perbedaan Vertikal dalam Struktur}

\section{Masyarakat Indonesia}

Selain perbedaan horizontal terjadi pula dari sisi vertikal. Adapun yang dimaksud dengan perbedaan vertikal yaitu perbedaan-perbedaan yang muncul melalui pembentukan lapisan atas dan lapisan bawah. Mereka hadir melalui entitas sosial berbasis perbedaan horizontal yang berujung pada perselingkuhan di akses politik dan kekayaan hingga menyebabkan terbentuk jurang pemisah antarentitas sosial. Kehadiran entitas sosial ini bersifat semu, rentan, ringkih dan penuh kecurigaan serta kehilangan kepercayaan (trust) sehingga daya kontrol satu sama lain makin tajam dan sensitif. Setelah reformasi isu tambahan berupa etnis Jawa dan luar Jawa turut menyemarakan perbedaan vertikal seiring dengan pengerucutan politik dan ekonomi yang mengusung isu-isu kemiskinan dan putra daerah. Isu-isu ini kerap menjadi sajian utama di setiap kampanye pemilihan presiden maupun kepala-kepala daerah.

Berkelidan perbedaan-perbedaan horizontal dan vertikal yang berujung pada tidak terlihat dan tidak terakomodasikan posisi dan kepentingan masyarakat adat sendiri. Mereka seolah-olah tidak berarti dan tidak ada. Peristiwa dan sikap demikian menjadi benar adanya jika pertarungan dan kontestasi antaraktor intelektual organis berlangsung dan 
berkutat di seputar entitas sosial. Kontestasi dan pertarungan telah terjadi di masa sebelum dan sesudah terbentuknya negara (Indonesia). Deklarasi Sumpah Pemuda sekurang-kurangnya merupakan representasi dari bibit-bibit perbedaan sebelum kemerdekaan, dan pada pasca kemerdekaan mereka mengelompok yang dikenal dengan rezim yang memerintah atau the ruling class meminjam istilah Mosca. Adagium politik, "merebut kekuasaan jika belum diperoleh dan dipertahankan selama mungkin dengan berbagai cara jika kekuasaan itu sudah di tangan”. Oleh karena itu mereka menjadi terlalu sibuk menyusun strategi pertahanan dan berupaya keras memenuhi kepentingan kelompoknya. Sehingga tak ayal posisi masyarakat adat lantas terdepak dari konstelasi kelompok-kelompok yang terajut membentuk masyarakat dalam untaian khatulistiwa tadi.

Mereka atau kelompok masyarakat adat ini oleh Marx diklasifikasikan sebagai kelas lumpen proletariat. Dalam bahasa populer atau keseharian adalah sekelompok atau segolongan kecil orang yang tidak berguna. Termasuk diantaranya pengemis, gelandangan, pencuri dan orang gila. Mereka tidak masuk dalam hitungan dan dalam konteks apapun, di dalam kehidupan berbangsa dan bernegara. Andaikan mereka ini hidup di negara zionis (Israel), mereka sudah sejak awal dimusnahkan dan tidak diperbolehkan hidup ditengah masyarakat ketika tanda-tanda bakal masuk klasifikasi lumpen proletariat; karena dianggap sangat memberatkan negara (kibult) dan tidak menghasilkan apapun yang lebih produktif. Tepatnya, rezim tidak ingin berurusan dengan orang-orang semacam ini karena memang tidak memberikan kontribusi dalam bentuk apapun kepada negara.

Ideologi Pancasila tentu tidak sekejam itu. Pancasila dengan kebhinnekaan seharusnya mampu sebagai penopang dan sandaran bagi setiap anak bangsa termasuk masyarakat adat dalam kehidupan berbangsa, namun kenyataan itu belum sepenuhnya terealisir. Pancasila masih terlalu sibuk berurusan dan mengalami problem internalnya sendiri. Sebagai contoh, kita mungkin bertanyatanya ada apa dengan Pancasila yang lahir 1 Juni 1945 yang selalu dihidupkan dan didengungkan di setiap pertemuan massa terbuka ketika temanya mengangkat Pancasila oleh salah satu parpol pendukung pemerintah terpilih saat ini, dibandingkan dengan Pancasila yang secara formal lahir pada 18 Agustus 1945! Apakah berkenaan dengan persoalan identitas, ataukah ada hubungan dengan status politik?

Problem internal tersebut tentu saja terciprat ke dunia Internasional. Dalam kancah global Indonesia adalah bagian darinya. Meski mungkin bagi negara- 
negara lain tidak ada persoalan tetapi jika sistem ekonomi dan pemerintahan semacam itu (tidak jelas) yaitu tidak liberal dan tidak sosialis (Budiman, 1987: 71) maka hasil akhirnya menjadi tidak optimal. Meski para founding fathers termasuk Soepomo menyebut sosioreligius dan integralistik sebagai wujud dan tujuan akhir fondasi bangsa ini, atau tokoh-tokoh lain dengan segala gagasannya. Sedikit lebih mudah terkait penjelasan secara filosofis tetapi sangat problematik ditataran empiris. Sehingga tidak terlalu salah jika rezim Soeharto berupaya menerjemahkan dan menginterpretasikan sendiri melalui P4 (Pedoman Penghayatan dan Pengamalan Pancasila) dengan 36 kristalisasi dan dapat dikembangkan menjadi lebih dari 100 butir sebagai dasar-dasar perilaku manusia Indonesia dalam berbangsa dan bernegara.

Rezim Soekarno lain lagi. Tokoh kaliber dunia ini sempat mensimulasikan dengan memeras Pancasila menjadi Trisila bahkan dapat diringkas hingga Ekasila alias Gotongroyong. Sementara tafsiran lain, sebagaimana kita lihat dan buktikan melalui penerjemahan Pancasila ke Batang Tubuh UUD 1945 hingga diamandemen maupun UUPA 1960 (Undang-undang Pokok Agraria); keseluruhan penjelasan yang ada tidak memberikan ruang dan singgungan yang berarti bagi kehadiran masyarakat adat untuk berkiprah. Namun sebaliknya ada beberapa undang-undang seperti UU Sumberdaya Air, UU Lingkungan Hidup, UU Kehutanan, UU ESDM serta berbagai peraturan daerah seluruh Indonesia ternyata memiliki variannya sendiri.

Kelihatannya sosok rezim yang bermukim di wilayah administratifpemerintahan didominasi dan dilingkupi oleh ekologi laut dan hutan dengan segala sistem ikutannya, dapat disimpulkan (secara acak) bahwa para intelektual organis ini jauh lebih empatif terkait masyarakat adat di wilayahnya. Kenyatan tersebut dapat dilihat dari peraturan daerah tentang tataruang dan wilayah (RT/RW) dan lain sebagainya; di mana pilihanpilihan dan penetapan regulasi suprastruktur kelembagaan yang merupakan bagian terbesar dari sosiokultural masyarakatnya jauh lebih mendapatkan penghargaan, penghormatan dan pengagungan dari mereka.

\section{Kebhinnekatunggalikaan sebagai Basis Integrasi Bangsa}

Apa yang tergambar di atas dengan dimensi-dimensi vertikal dan horizontal adalah upaya untuk mendekatkan realitas sosial melalui etnografi-etnografi sebagai sebuah kenyataan. Gambaran semacam ini tidak terhampar secara utuh seiring dengan hadirnya negara. Pancasila yang selama ini diyakini, dianalisis, dan selalu berkutat seputar ketatanegaraan dan lain 
sebagainya, dengan politik-hukum ditempatkan sebagai panglima; selain juga ada yang mengembangkan nilai-nilai itu melalui budaya karena memang Pancasila digali dari akar-akar dan nilai budaya bangsanya. Namun sayang (Soetiknjo, 1985: 17) pemahaman dan perkembangannya ternyata tidak terlalu direspons dengan cukup baik oleh para intelektual organis kita. Kebudayaan yang terbentuk, bisa jadi, diposisikan hanya -meminjam pendekatan evolusioner baku berlandaskan pemikiran Malinowski dan Radcliffe-Brown atau antropolog Boassangat berorientasi pada tujuan dan mengabaikan proses, atau diringkas sebagai "pembangunan" itu.

Pemahaman Pancasila berbasis kebudayaan mestinya tidak lagi dipandang sebagai manifestasi sekuensial sebuah kisah yang mengalir runtut begitu saja; juga bukan pula hanya membentang dari zaman di mana manusia belum mengenal peradaban hingga ke puncak-puncak peradaban, melainkan sebagai sesuatu yang harus "dilakukan" oleh orang-orang secara kolektif dengan cara yang berbeda-beda, di tempat dan waktu yang juga berbeda-beda (Jenks, 2013: 46). Merujuk fakta historis demikian itulah warna dan corak masyarakat kita dalam berbangsa harus diakui sebagai plural dan heterogen. Pengakuan demikian dibaca dengan sangat baik oleh pemerintah kolonial dan dieksplisitkan dengan membagi-bagi Indonesia itu dalam golongan-golongan, yaitu yang menjadi golongan kelas utama adalah Eropa khususnya Belanda, menyusul Timur Asing yang didominasi Tionghoa sebagai golongan kedua, dan golongan terbawah adalah kita/pribumi (Inlander). Tentu tujuannya, untuk memecah-belah bangsa.

Masa itu pemerintah kolonial membaginya berdasar aspek sosialekonomi-politik-kultural dengan aspek politik sebagai pemacu guna mempertahankan kekuasaan tetapi setelah merdeka pembacaan berubah. Intelektual organis lebih menekankan aspek-aspek penggolongan berdasar ekonomi-politik. Konsekuensi atas tekanan ini menyebabkan Indonesia terbelah menjadi: mereka yang memiliki kapital besar tetapi dengan jumlah kecil orang, dan sisanya adalah jumlah terbesar orang tetapi tidak memiliki modal sama sekali. Sehingga golongan yang terbentuk menjadikan: mereka yang berpunya dan mereka yang tidak berpunya. Sementara rajutan lain secara horizontal tersegmentasi menjadikan mereka dalam bagian-bagian kecil mengikuti garis keturunan dan kedaerahan. Posisi sisanya, dalam horizontal tadi, adalah golongan lumpen proletariat (masyarakat adat termasuk orang gila dan segolongan yang tidak berguna lainnya) tidak 
diperhitungkan dalam kancah ekonomipolitik nasional.

Berdasarkan penggolongan hingga membentuk struktur dengan mana struktur atas melalui hegemoni atau ideologi yang dibawa "merembes" keseluruh sendi-sendi kehidupan berbangsa dan bernegara. Dengan kemampuan koersif dan "penyadaran" ideologi yang berujung pada upaya untuk "mendapat restu" atau persetujuan masyarakat (termasuk masyarakat adat), sehingga rezim alias intelektual organis dapat menjalankan roda pemerintahan tanpa gangguan. Membungkus setiap kebijakan dengan istilah pembangunan dan kesejahteraan, bahkan rezim sekarang melambungkan KIS (Kartu Indonesia Sehat), KIP (Kartu Indonesia Pintar), dan KKS (Kartu Keluarga Sejahtera) adalah strategi manipulatif yang membius masyarakat termasuk masyarakat adat agar dengan dan atas nama pembangunan melalui istilah "sosial dan kepentingan umum" dalam titik kulminasi yang mematikan. Masyarakat adat secara "sadar" lantas melepaskan sumber-sumber kehidupannya dan lantas beralih pemilik (baca: kekuasaan) ke tangan para pemodal.

Cara hegemonik demikian dapat berlangsung sempurna tanpa merasa bersalah jika telah merugikan anak bangsanya. Mereka yakin jika tindakan yang dilakukan benar adanya. Perihal demikian dapat terjadi karena para intelektual organis ini di masa kolonial belajar dan menimba ilmu di luar negeri terutama di negeri induk jajahan (Belanda), sehingga tak ayal cara berpikir dan bertindak lebih berempati kepada pemerintah kolonial daripada penderitaan anak bangsanya. Hegemoni atau ideologi pemikiran menjalar ke seluruhan jaringan birokrasi pemerintahan kolonial. Di sinilah Toffler (1988: 327) mengingatkan bahwa, perilaku semacam itu sebagai satu rangkaian yang menghasilkan peradaban dan lantas menjualnya ke seluruh planet bumi termasuk Indonesia sebagai bentuk pemerintahan yang baru, paling efisien, dan paling manusiawi yang dapat dibayangkan. Namun praktik-praktik kebijakan semacam itu hanya suatu kamuflase atau bayang-bayang belaka.

Persoalannya sekarang, melalui kebhinnekaan dengan menjual isu "pembangunan dan kepentingan umum" pastinya berakhir pada penciptaan keseragaman dalam bahasa, nilai-nilai, mesin-mesin, cara kerja, arsitektur, pandangan politik, dan gaya hidup pada umumnya. Singkat kata menghasilkan "masyarakat massa". Dalam posisi "masyarakat massa" semacam itu memudahkan pergerakan setiap kebijakan, namun karena kesadaran diri untuk berempati atas masyarakat adat tidak terbentuk maka tentu saja semakin lama 
semakin sulit untuk mencapai konsensus secara lokal sekalipun!

Selebihnya intelektual organis sebagai sebuah rezim yang saat ini sedang duduk di legislatif maupun eksekutif, sejauh dipahami, ternyata tidak pernah dirancang untuk menanggulangi tingkat keanekaragaman ini. Jika pun belakangan ada sekelompok masyarakat (adat) melalui anak-anak mereka yang secara ekonomi tidak mampu tetapi memiliki kecerdasan di atas rata-rata dan ketika mengambil pendidikan di sekolah-sekolah formal hingga ke perguruan tinggi atas beasiswa; tetapi ketika mereka sudah menyelesaikan pendidikannya maka mereka tidak pernah kembali lagi ke habitat atau sosiokulturalnya. Mereka menjadi sosok intelektual organis "baru" yang politik kebijakannya juga seirama dengan intelektual organis yang merekrutnya.

Jika demikian, Bhinneka Tunggal Ika dalam cengkraman burung garuda yang dikalungi Pancasila yang menunjuk arti "persatuan dalam perbedaan" nampaknya masih berhenti di sini. Sampai kapankah kita dengan masyarakat adat mampu dan siap menjadi "kita bersama dan bersama kita?". Padahal masyarakat atau suatu sistem sosial senantiasa terintegrasi di atas dua landasan, yaitu: pertama, suatu masyarakat senantiasa terintegrasi di atas tumbuhnya konsensus diantara sebagian anggota masyarakat di atas nilai-nilai kemasyarakatan yang dijunjung bersama dan bersifat fundamental. Kedua, suatu masyarakat senantiasa terintegrasi dalam satu solidaritas yang diakui bersamat sekaligus sebagai satu bagian dari satu solidaritas yang lain dalam berbagai kesatuan sosial (cross-cutting affiliations) (Nasikun, 1989: 69). Jika demikian patutlah dipertanyakan sejauhmana ideologi Pancasila dengan kebhinnekaan yang dipraktikkan rezim berkuasa mampu bersikap dan dimana pula posisi dan peran negara terkait masyarakat adat ini?

\section{Masyarakat Adat dalam Dilema dan Ancaman}

Kesenjangan terhadap apa yang seharusnya dilakukan oleh negara tentu saja harus menunjuk pada akar persoalan. Pada dasarnya masyarakat adat tanpa negara dapat survive. Sehingga penempatan masyarakat adat dalam beragam kasus sebagai daerah tertinggal dan terluar (bahasa pemerintah), sangatlah tidak tepat sasaran. Sejauh dilihat dari perspektif sosiokultural posisi mereka labil akibat goncangan dan penempatan yang salah sasaran tadi, sehingga karenanya tidak ada artinya kita bicara integrasi apalagi nasionalisme? Dalam kerangka kerja demikian itulah Taylor-Gooby dan Dale (dalam Ife dan Frank Tesoriero, 2008: 109-116) mencoba merumuskan berdasar pertimbangan isu sosial tatkala 
menetapkan perspektif yang sesuai dalam menyikapi masyarakat adat ini.

Pertimbangan-pertimbangan dalam Isu Sosial

\begin{tabular}{|l|l|l|l|}
\hline PERSPEKTIF & \multicolumn{1}{|c|}{$\begin{array}{c}\text { SUMBER } \\
\text { KESALAHAN }\end{array}$} & \multicolumn{1}{|c|}{$\begin{array}{c}\text { PERSEPSI ATAS } \\
\text { MASALAH }\end{array}$} & \multicolumn{1}{c|}{ SOLUSI } \\
\hline Individual & $\begin{array}{l}\text { Menyalahkan } \\
\text { korban }\end{array}$ & $\begin{array}{l}\text { Patologi individual; } \\
\text { psikologis, cacat moral } \\
\text { atau watak }\end{array}$ & $\begin{array}{l}\text { Terapi, perawatan me- } \\
\text { dis, modifikasi } \\
\text { perilaku, dukungan } \\
\text { moral, kontrol }\end{array}$ \\
\hline $\begin{array}{l}\text { Reformasi } \\
\text { kelembagaan }\end{array}$ & $\begin{array}{l}\text { Menyalahkan } \\
\text { penolong }\end{array}$ & $\begin{array}{l}\text { Lembaga-lembaga yang } \\
\text { dibentuk untuk } \\
\text { mengurus masalah } \\
\text { tersebut }\end{array}$ & $\begin{array}{l}\text { Reorganisasi lembaga- } \\
\text { lembaga, tambahan } \\
\text { sumberdaya, tambahan } \\
\text { layanan, pelatihan yang } \\
\text { lebih baik dsb. }\end{array}$ \\
\hline Struktural & $\begin{array}{l}\text { Menyalahkan } \\
\text { sistem }\end{array}$ & $\begin{array}{l}\text { Struktur-yang- } \\
\text { merugikan atau opresi: } \\
\text { kelas, ras, gender, } \\
\text { distribusi penda-patan, } \\
\text { kekuasaan dsb }\end{array}$ & $\begin{array}{l}\text { Perubahan struktural, } \\
\text { mengubah basis opresi, } \\
\text { revolusi }\end{array}$ \\
\hline Post-struktural & $\begin{array}{l}\text { Menyalahkan } \\
\text { wacana }\end{array}$ & $\begin{array}{l}\text { Modernitas, bahasa, } \\
\text { formasi dan akumulasi } \\
\text { pengetahuan, } \\
\text { pemahaman bersama }\end{array}$ & $\begin{array}{l}\text { Analisis dan pemaham- } \\
\text { an wacana, akses } \\
\text { kepada pemahaman, } \\
\text { menantang 'aturan' } \\
\text { dsb. }\end{array}$ \\
\hline
\end{tabular}

Sumber: Ife dan Frank Tesoriero (2008: 115)

Berdasarkan kajian Ife dan Frank Tesoriero, perspektif individu sudah tentu menekankan aspek individu katakanlah soal kemiskinan, pengangguran, depresi dan lainnya; tetapi pendekatan ini gagal karena persoalan terletak di luar diri individu yang tidak mampu dikendalikannya, katakan seperti distribusi pendapatan, patriaki, dan ketidakadilan pasar (market-induced inequality). Perspektif kelembagaan, kelemahannya terletak pada sistem peradilan "sumbang" dan karenanya justru memunculkan masalah baru seperti kriminalitas dan pelanggaran. Solusinya adalah penguatan kelembagaan dengan pengadaan rumah sakit dan sekolah. Maka itu hanya berkonsentrasi pada perbaikan masalahmasalah sosial daripada penyebabnya. Perspektif struktural terletak pada struktur sosial yang opresif dan tidak adil. Pendekatan ini berkonsentrasi pada isu-isu seperti patriaki, kapitalisme, rasisme, kelembagaan dan distribusi pendapatan di mana struktur yang merugikan sebagai isu utama yang harus ditangani. Resepnya adalah restrukturisasi masyarakat secara besar-besaran. Akibatnya pendekatan ini dikenal sangat radikal. Biasanya tidak 
terlalu laku dijual di negara-negara baru seperti Indonesia.

Akhirnya, perspektif post-strukturalis. Dalam perspektif ini, penyebab utama adalah penggunaan bahasa, penyampaian makna, formasi dan akumulasi pengetahuan, dan cara-cara yang digunakan untuk mengontrol dan mendominasi melalui pendefinisian hal-hal yang dianggap sesuai, perilaku yang dapatditerima dan seterusnya. Melalui bahasa kita mengontruksikan wacana kekuasaan (power discourse), dan di dalam konstruksi "kekuasaan diskursif" (discursive power) seperti opresi dan keadaan-yangmerugikan menjadi diabadikan. Pendekatan ini diametral dengan pendekatan struktural. Sehingga lebih tepat disebut sebagai "menyalahkan wacana". Mereka lebih mencari pemahaman makna, yang memungkinkan orang untuk membantu membentuk wacana alternatif. Apa yang kelihatan sebagai titik-titik kelemahan senantiasa berubah dan dapat dieksploitasi untuk tujuan-tujuan politik tertentu. Artinya, post-strukturalis mendorong suatu keanekaragaman konstruksi "dari masalah dan dari solusi"; jadi tidak ada satu jawaban yang "benar".

Berkenaan dengan masyarakat adat kita nampak perspektif post-strukturalis lebih relevan. Sebagaimana masyarakat adat sesungguhnya "tidak perlu negara" maka pemberian ruangan dan legitimasi bagi suara-suara alternatif untuk didengar dan disahkan, dan bagi munculnya wacana alternatif daripada bersikukuh seraya "menunggu kepunahannya" (lihat pasal demi pasal UUD 1945 dan turunannya). Itulah jawabannya. Akhirnya perlu kita renungkan apa yang ditulis Soetrisno (2000: xxi) dalam Kata Pengantar buku, Senjatanya Orang-orang yang Kalah, karya James C. Scott bahwa “...dunia saat ini, juga, dihuni oleh manusia-manusia gila yang mampu menciptakan mesin-mesin pembunuh yang sangat canggih. Kelompok seperti ini bergabung dengan kelompok radikal lokal untuk mengganggu keamanan. Hal ini tidak dapat dicegah dengan kekuatan militer tetapi hanya mungkin dicegah oleh satu pemerintahan yang demokratis, yang menghormati hakhak asasi manusia, dan bersih". Apakah peringatan Soetrisno itu menunjuk keterbuktiannya, tatkala menyimak tayangan di Youtube dimana kelompok ISIS (Negara Islam Irak dan Suriah/Syam) begitu berani menantang TNI, Polri dan Banser. Aktor atau pelakunya adalah anak bangsa lokal-sendiri bersama kekuatan luar di Suriah. Apakah tidak dapat diartikan bahwa tayangan itu dianggap sebagai sebuah bentuk perlawanan akibat disingkirkan dan tidak dihargai akan harkat dan martabatnya sebagai salah satu anak bangsa? 


\section{DAFTAR PUSTAKA}

Bachtiar, Harsja, W., 1976. "Masalah Integrasi nasional". Prisma. LP3ES. Nomor 8.

Budiman, Arief, 1996. Teori Negara: Negara, Kekuasaan dan Ideologi. PT Gramedia. Jakarta.

Budiman, Arief, 1987. "Kebudayaan kekuasaan atau Sosiologi Kekuasaan". Prisma. LP3ES. Nomor 3.

Femia, Joseph, V, 1987. Gramsci's Political Though. Clarendonpress. Oxford.

Gramsci, Antonio, 2013. Prison Notebooks: Catatan-catatan dari Penjara. Pustaka Pelajar. Yogyakarta.

Ife, Jim dan Frank Tesoriero, 2008. Community Development. Pustaka Pelajar. Yogyakarta'

Jenks, Chris, 2013. Culture: Studi Kebudayaan. Pustaka Pelajar. Yogyakarta'
Nasikun, 1989. Sistem Sosial Indonesia. Rajawali. Jakarta'

Sanderson, Stephen K., 2003. Sosiologi Makro. Rajawali. Jakarta'

Soetiknjo, Iman, 1985. Politik Agraria Nasional. Gadjah Mada University Press. Yogyakarta'

Soetrisno, Loekman, 2000. "Pengantar". Dalam, James C. Scott. Senjatanya Orang-Orang yang Kalah. Yayasan Obor Indonesia. Jakarta'

Sutherland, Heather, 1983. Terbentuknya Sebuah Elite Birokrasi. Sinar harapan. Jakarta'

Toffler, Alvin, 1988. 'Krisis Pemerintahan Demokratis'. Dalam, D.C Korten dan Sjahrir, Penyunting. Pembangunan Berdimensi Kerakyatan. Yayasan Obor Indonesia. Jakarta'

Wertheim, W.F, 1999.Masyarakat Indonesia dalam Transisi. Tiara Wacana.

Yogyakarta 